\title{
Sequence Stratigraphic Framework and Application to the Precambrian
}

\author{
Octavian Catuneanu ${ }^{1}$, Marcelo A. Martins-Neto ${ }^{2}$ and Patrick G. Eriksson ${ }^{3}$ \\ 1 Department of Earth and Atmospheric Sciences, University of Alberta, 1-26 Earth Sciences Building, \\ Edmonton, Alberta, T6G 2E3, Canada \\ Vale Óleo \& Gás, Av. Graça Aranha 26, 4th floor, ZIP 20020-900, Rio de Janeiro, Brazil \\ Department of Geology, University of Pretoria, Pretoria, 0002, South Africa
}

\begin{abstract}
Sequence stratigraphy highlights stratal stacking patterns and changes thereof within a time frame. Each stratal stacking pattern defines a particular genetic type of deposit with a unique geometry and sediment dispersal pattern within the basin. Common genetic types of deposit are referred to as 'forced regressive', 'lowstand normal regressive', 'transgressive', and 'highstand normal regressive'. These genetic units are the basic building blocks of the sequence stratigraphic framework at any scale of observation, and are bounded by sequence stratigraphic surfaces. The recurrence of the same types of sequence stratigraphic surface through geologic time defines cycles of change in accommodation or sediment supply, which correspond to sequences in the rock record. Depending on the scale of observation, sequences and sequence stratigraphic surfaces may be ascribed to different hierarchical orders.
\end{abstract}

The concept of accommodation, which defines the space available for sediments to fill, is central to sequence stratigraphy. Changes in accommodation are in part controlled by regional to local tectonism, and therefore are location specific. The construction of accommodation curves is based on Wheeler diagrams, the preserved thickness of sequences, and the paleodepositional environment. Accommodation curves may or may not correlate between different sedimentary basins, or even between different sub-basins of the same sedimentary basin, depending on the interplay of local versus global controls on sedimentation. The offset between the accommodation curves that characterize different depozones tends to increase for cycles of increasingly lower rank.

While the workflow and principles of sequence stratigraphy remain the same irrespective of the age of strata under analysis, the differences and similarities between the Phanerozoic and the Precambrian rock record provide significant clues to improving our approach to the application of the sequence stratigraphic method.

Keywords: sequence stratigraphy; Precambrian; sequence hierarchy; accommodation curves.

\section{Introduction}

Sequence stratigraphy is uniquely focused on the analysis of stratal stacking patterns and changes thereof within a time frame. Stratal stacking patterns form in response to the interplay of accommodation (space available for sediments to fill) and sedimentation, and reflect 
combinations of depositional trends that include progradation, retrogradation, aggradation and downcutting.

Sequence stratigraphy was developed as a new method of stratigraphic analysis based primarily on Phanerozoic case studies. It was generally assumed that conclusions drawn from the study of the Phanerozoic record would be universally applicable to strata of all ages, following the principle of uniformitarianism. This approach was debated and placed under scrutiny in recent years (e.g., Eriksson et al., 2004a; Catuneanu et al., 2005). It is now accepted that both similarities and differences exist between the patterns of sedimentation within Precambrian and Phanerozoic depositional settings. In terms of similarities, the same set of controls on sedimentation operated throughout geological time; such controls include the interplay of plate tectonic and mantle-thermal processes, modified by the influence of eustasy and paleoclimate (e.g., Eriksson et al., 2001a and b, 2004a and b, 2005a). The effects of the same set of underlying allogenic controls on sedimentation lead to marked similarities with respect to preserved lithologies, sedimentary structures, and the association of sedimentary facies and depositional elements within Precambrian and Phanerozoic sedimentary basins. Such observations lead to the conclusion that the origin of almost all Precambrian sedimentary facies has counterparts in modern environments (e.g., Eriksson et al., 1998; Altermann and Corcoran, 2002).

Differences between Precambrian and Phanerozoic sedimentary-basin fills are caused by changes in environmental-energy conditions and the related physical processes; the evolution of competing groups of organisms; and changes in the rates and intensities of processes controlling various aspects of sedimentation at different scales of observation (e.g., Catuneanu, 2007). The latter type of changes include variable rates of plate drift coupled with variable rates of continental crustal growth (e.g., Catuneanu, 2001; Arndt, 2004; Cousens et al., 2004; Eriksson and Catuneanu, 2004); the change in the gravitational effects of the moon on sedimentation over time, together with a gradually decreasing rotation rate for the Earth (Williams, 2004); the lack of vegetation during the Precambrian coupled with the long-term evolution of the planet's hydrosphere-atmosphere-biosphere system (Grotzinger, 1990; Pflüger and Sarkar, 1996; Eriksson et al., 2000; Altermann, 2004; Ohmoto, 2004; Schopf, 2004; Sarkar et al., 2005); and variations in the rates of weathering, erosion, transport, deposition and diagenesis (e.g., Donaldson et al., 2002; Eriksson et al., 2004a and c). All these changes contributed to differences in the scale and architecture of Precambrian sequences when compared with Phanerozoic counterparts (e.g., Catuneanu, 2007).

While hampered by practical limitations, such as lesser preservation and poorer time control, the Precambrian enlarges our window into the geological past and affords better insights into some of the first principles of sequence stratigraphy. This paper reviews the fundamental concepts of sequence stratigraphy that are used in this volume, and examines the application of sequence stratigraphy to the Precambrian rock record. 


\section{Fundamental concepts}

\subsection{Accommodation}

The concept of 'accommodation' defines the space available for sediments to fill (Jervey, 1988). Accommodation may be modified by the interplay between various independent controls which may operate over a wide range of temporal scales. Marine accommodation is controlled primarily by basin tectonism and global eustasy, and, over much shorter time scales, by fluctuations in the energy flux of waves and currents. Changes in marine accommodation are referred to as relative sea-level changes, when emphasis is placed on the interplay of tectonism and eustasy, or as base-level changes, when the energy flux of the depositional setting is also considered. Fluvial accommodation responds to changes in marine accommodation within the downstream portion of fluvial systems, and to changes in discharge, gradient and sediment supply that may be controlled by climate, atmospheric composition (in the case of Precambrian examples) and/or source area tectonism within the upstream portion of fluvial systems.

\subsection{Accommodation curves}

The nature of the reference curve that is utilized to define sequence stratigraphic surfaces and systems tracts varies with the sequence stratigraphic model. Candidates for application to this curve include eustasy, relative sea level, and base level (Fig. 1). The concept of 'base-level change' is more comprehensive than all other candidates for a reference curve, as it accounts for both the long-term (e.g., eustasy, tectonism) and the short-term (e.g., fluctuations in environmental energy flux) controls on accommodation (see full discussion in Catuneanu, 2006).

Eustatic curves are difficult to reconstruct from the architecture of the stratigraphic record, because the relative importance of eustasy and tectonism on accommodation in underfilled basins is, in most cases, difficult to discriminate and quantify. This realization came in the 1990's, when the early global cycle charts of the Exxon group fell under intense scrutiny (e.g., Miall, 1991, 1992, 1995). Eustatic curves can however be reconstructed from independent isotope studies (e.g., Miller et al., 1998, 2004), or even from the stratigraphic record in cases where the effects of tectonism can be demonstrated as having been negligible at the time of sedimentation (i.e., in tectonically stable basins; Haq, 2009).

Relative sea-level curves combine the effects of eustasy and tectonism, without attempting to discriminate between their relative importance, and work well in underfilled basins where a marine environment is present. However, such curves cannot be used to describe cyclicity in overfilled basins, or in the updip-controlled portion of sedimentary basins where processes of fluvial aggradation or incision may be offset relative to the timing of sea-level or relative sealevel changes.

Considering the limitations imposed by the eustatic and relative sea-level curves, the accommodation curves provide the viable solution to illustrate the timing of formation, as well as the relative importance, of sequences and sequence boundaries in all settings, from underfilled to overfilled. The construction of accommodation curves is based on the combination of 
information from Wheeler diagrams, the preserved thickness of sequences, as well as paleogeographic and paleobathymetric data.

\subsection{Stratal stacking patterns}

Stratal stacking patterns are defined on the basis of geometries and facies relationships that emerge from the interplay of available accommodation and sediment supply at syn-depositional time. All conventional sequence stratigraphic models (Fig. 1) account for stratal stacking patterns that can be tied to specific types of shoreline trajectory: forced regression (forestepping and downstepping at the shoreline, interpreted as the result of negative accommodation); normal regression (forestepping and upstepping at the shoreline, interpreted as the result of positive and overfilled accommodation); and transgression (backstepping at the shoreline, interpreted as the result of positive and underfilled accommodation) (Fig. 2). In the case of stratigraphic cycles that include a stage of forced regression as well as a stage of transgression, normal regressions can occur during both lowstands and highstands of relative sea level and, consequently, the products may be classified as 'lowstand' and 'highstand' deposits.

Each type of stratal stacking pattern defines a particular genetic type of deposit with a distinct geometry and facies preservation style (Fig. 2). These genetic units are the basic building blocks of any sequence stratigraphic framework, at any scale of observation (Fig. 3). At smaller scales, normal regressive, forced regressive and transgressive deposits contribute to the makeup of parasequences, which are essentially prograding lobes bounded by flooding surfaces (Van Wagoner et al., 1988, 1990). At larger scales, overall normal regressive, forced regressive and transgressive trends define systems tracts, which are linkages of contemporaneous depositional systems that form the subdivisions of sequences (Brown and Fisher, 1977) (Fig. 3).

\subsection{Sequence stratigraphic surfaces}

Sequence stratigraphic surfaces are surfaces that can serve, at least in part, as systems tract and sequence boundaries. These surfaces include subaerial unconformities, correlative conformities, maximum flooding surfaces, maximum regressive surfaces, transgressive ravinement surfaces and regressive surfaces of marine erosion. Not all types of data afford the recognition of all sequence stratigraphic surfaces, and not all sequence stratigraphic surfaces are present in every depositional setting. The area of transition between fluvial and shallow-water systems affords the formation of the entire array of sequence stratigraphic surfaces. In contrast, within fluvial and deep-water systems, conditions are favorable for the formation of fewer key bounding surfaces (Catuneanu et al., 2009, 2010).

The criteria that can be used to identify each sequence stratigraphic surface include: the conformable versus unconformable nature of the contact; the depositional systems below and above the contact; the depositional trends below and above the contact; the types of substratecontrolled ichnofacies associated with the contact; and stratal terminations associated with the contact (see fig. 4.9 in Catuneanu, 2006, for a review of criteria; Catuneanu et al., 2009, 2010).

The recurrence of the same types of sequence stratigraphic surface through geologic time defines cycles of change in accommodation or sediment supply, which correspond to sequences in the 
rock record. Depending on the scale of observation, sequences and sequence stratigraphic surfaces may be ascribed to different hierarchical orders.

\section{Sequence models}

A "sequence" corresponds to a cycle of change in accommodation or sediment supply (Catuneanu et al., 2009). Several different types of sequence have been proposed and are currently in use (Figs. 4, 5). Each of these approaches (models) as to how the sequence stratigraphic method should be applied to the rock record has its own merits and pitfalls. A brief review of the different types of sequence follows below (from Catuneanu et al., 2009, 2010).

\subsection{Depositional sequences}

A depositional sequence forms during a full cycle of change in accommodation, which involves both an increase (positive) and decrease (negative) in the space available for sediments to fill. The formation of depositional sequence boundaries (i.e., subaerial unconformities and one of two types of correlative conformities; Fig. 5) requires periods of negative accommodation. The dependency of depositional sequences on negative accommodation (whether in continental or marine settings), in addition to the nature of bounding surfaces, separates depositional sequences from other types of sequence stratigraphic units, the formation of which may not require negative accommodation (i.e., parasequences, genetic stratigraphic sequences, transgressive-regressive sequences in the sense of Johnson and Murphy (1984), and systems tracts that form during positive accommodation).

\subsection{Genetic stratigraphic sequences}

The formation of genetic stratigraphic sequences depends on the development of maximum flooding surfaces, which form during times of positive accommodation. A genetic stratigraphic sequence may form during a full cycle of change in accommodation, as in the case of a depositional sequence, but it may also form during periods of positive accommodation in response to fluctuations in the rates of accommodation creation and/or sediment supply. Consequently, a genetic stratigraphic sequence may or may not include an internal subaerial unconformity, depending on whether or not the corresponding cycle includes a stage of negative accommodation. Maximum flooding surfaces may include unconformable portions expressed as "hiatal surfaces preserved as marine unconformities" (Galloway, 1989). Such unconformities may develop on the shelf and slope because of sediment starvation, shelf-edge instability and erosion during transgression. Where present, unconformable maximum flooding surfaces are included within but do not constitute the bounding surfaces defining depositional sequences and transgressive-regressive sequences.

\subsection{Transgressive-regressive (T-R) sequences}

The original T-R sequence of Johnson and Murphy (1984) depends on the development of maximum regressive surfaces, which form during times of positive accommodation. As in the case of genetic stratigraphic sequences, this type of sequence may form during a full cycle of 
change in accommodation, but it may also form during periods of positive accommodation as a result of fluctuations in the rates of accommodation and/or sediment supply. By contrast, the T-R sequence of Embry and Johannessen (1992) is dependent on negative accommodation, as it requires a subaerial unconformity at the sequence boundary. As the maximum regressive surface is younger than the subaerial unconformity, the marine portion of the maximum regressive surface may or may not meet with the basinward termination of the subaerial unconformity (Embry and Johannessen, 1992). The temporal and spatial offset between the two portions of the sequence boundary is increasingly evident at larger scales of observation (Catuneanu et al., 2009).

\section{Hierarchy}

The definition of sequences and systems tracts is independent of spatial and temporal scales. The relative significance of sequence stratigraphic units that develop at different scales of observation is resolved via the concept of hierarchy. This concept refers to the definition of different orders of cyclicity on the basis of their relative stratigraphic significance.

Different proposals on how to define a hierarchy system (e.g., Vail et al., 1977, 1991; Mitchum and Van Wagoner, 1991; Embry, 1995; Krapez, 1996, 1997) have stimulated active discussions within the stratigraphic community (e.g., Miall, 1995, 1997; Drummond and Wilkinson, 1996; Schlager, 2004; see recent summaries in Catuneanu et al., 2009, 2010). A limiting factor in the way of defining a universally applicable hierarchy system is that the interplay of competing sequence-forming mechanisms results in the formation of stratigraphic cycles across a continuum of temporal and spatial scales (Drummond and Wilkinson, 1996; Schlager, 2004). In the absence of discrete modes within the wide continuum of scales, hierarchical subdivisions often remain arbitrary and may only be basin specific (Catuneanu et al., 2009, 2010).

The application of sequence stratigraphy to the Precambrian rock record has significantly improved our insights into the definition of criteria for a system of stratigraphic hierarchy. A critical aspect is that the rates and concomitantly even partly, the nature of basin-forming mechanisms has changed during Earth's evolution, from a greater measure of competing plume tectonics and plate tectonics in the Precambrian to a more stable plate-tectonic regime in the Phanerozoic (Eriksson and Catuneanu, 2004; Eriksson et al., 2005a, b). The more erratic nature of the tectonic regimes which controlled the formation and evolution of sedimentary basins in the Precambrian indicates that time is largely irrelevant as a parameter in the classification of stratigraphic sequences. Instead of time, it is rather the record of changes in the tectonic setting that provides the means for the subdivision of the stratigraphic record into basin-fill successions separated by first-order sequence boundaries. These first-order basin-fill successions are in turn subdivided into second- and lower-rank sequences that result from shifts in the balance between accommodation and sedimentation at various scales of observation, irrespective of the time span between two same-order consecutive events.

Sequences identified in any particular basin are not expected to correlate to sequences of other sedimentary basins, unless their formation may be linked to global controls. The lower the hierarchical rank of stratigraphic cycles the greater the possibility for only a local relevance of 
those cycles, due to the potentially increased influence of local controls on accommodation. A full discussion on the issue of hierarchy and the criteria that can be used to separate between orders of cyclicity is provided by Catuneanu (2006).

\section{Discussion and conclusions}

The method of sequence stratigraphy requires the application of the same workflow and principles irrespective of the age of strata under analysis (Fig. 6). In that respect, its application to Precambrian successions is similar to the approach used for Phanerozoic case studies. Differences, however, are recorded in terms of the preservation potential and the amount of data available for analysis; the rates and intensities of the allogenic controls on sedimentation; the environmental conditions and related physical processes; and the evolution of competing groups of organisms and associated biogenic processes. The combined effect of these contrasting aspects may account for differences in the architecture of Precambrian depositional sequences, particularly with respect to the relative contributions of various systems tracts to the makeup of a sequence (e.g., Sarkar et al., 2005; Catuneanu, 2007).

The application of sequence stratigraphy to Precambrian basins has considerably enlarged the perspective on the fundamental principles governing the processes of sedimentary basin formation and the mechanisms controlling stratigraphic cyclicity in the rock record. These firstorder principles are perhaps the most important contribution of Precambrian research to sequence stratigraphy. At the broader scale of Earth's geological history, the tectonic regimes governing the formation and evolution of sedimentary basins are shown to have been much more erratic in terms of nature and rates than originally inferred solely from the study of the Phanerozoic record. This provides important clues with respect to the criteria that should be involved in the hierarchy system of classification of stratigraphic sequences and bounding surfaces.

Accommodation curves may be reconstructed based on geometries preserved in the rock record, including the thickness of topsets that form during normal regressions, the increase in the elevation of backstepping (transgressive) coastlines, the magnitude of downstepping during forced regressions, or the depth of fluvial incised valleys. However, such quantitative curves may only have local relevance due to variations in tectonic regimes and sediment supply from one

sedimentary basin to another, or between different sub-basins within the same sedimentary basin.

All sequences whose timing and origin are related to shoreline trajectories share the common element that they all consist of a combination of the same basic building blocks defined by normal regressive, transgressive and forced regressive stacking patterns. These building blocks compose any type of sequence stratigraphic unit, from sequence to systems tract and parasequence, at any scale of observation (Fig. 3; Catuneanu et al., 2009, 2010).

\section{Acknowledgements}

This paper builds upon the work published by Catuneanu et al., 2005, 2009, 2010, and is the result of the continuing effort to define a standard sequence stratigraphic methodology that 
should be applicable irrespective of stratigraphic age, scale of observation, or the types of data available for analysis. Research funding during the completion of this work was provided by the Natural Sciences and Engineering Research Council of Canada (NSERC), the University of Alberta (OC), the CNPq - Brazilian National Research Council (MAMN), and the University of Pretoria (PGE). We thank J. Daudt and A. Dave for insightful and constructive reviews.

\section{References}

Altermann, W., 2004. Precambrian stromatolites: problems in definition, classification, morphology and stratigraphy. In: Eriksson, P.G., Altermann, W., Nelson, D.R., Mueller, W.U., Catuneanu, O. (Eds.) The Precambrian Earth: Tempos and Events. Elsevier, Amsterdam, pp. 564-574.

Altermann, W., Corcoran, P.L. (Eds.), 2002. Precambrian Sedimentary Environments: A Modern Approach to Ancient Depositional Systems. I.A.S. Spec. Publ. 33, Blackwell, Oxford, 450 pp.

Arndt, N.T., 2004. Crustal growth rates. In: Eriksson, P.G., Altermann, W., Nelson, D.R., Mueller, W.U., Catuneanu, O. (Eds.) The Precambrian Earth: Tempos and Events. Elsevier, Amsterdam, p. 155-158.

Brown, L.F., Jr. and Fisher, W.L., 1977. Seismic stratigraphic interpretation of depositional systems: examples from Brazilian rift and pull apart basins. In: C.E. Payton (ed.) Seismic Stratigraphy - Applications to Hydrocarbon Exploration. American Association of Petroleum Geologists Memoir 26, p. 213-248.

Catuneanu, O., 2001. Flexural partitioning of the Late Archaean Witwatersrand foreland system, South Africa. Sedimentary Geology, v. 141/142, p. 95-112.

Catuneanu, O., 2006. Principles of Sequence Stratigraphy. Elsevier, Amsterdam, 375 pp.

Catuneanu, O., 2007. Sequence stratigraphic context of microbial mat features. In: Schieber, J., Bose, P.K., Eriksson, P.G., Banerjee, S., Sarkar, S., Altermann, W. and Catuneanu, O. (Eds.) Atlas of Microbial Mat Features Preserved within the Siliciclastic Rock Record. Atlases in Geosciences, 2, Elsevier (Amsterdam), p. 276-283.

Catuneanu, O., Martins-Neto, M.A. and Eriksson, P.G., 2005. Precambrian sequence stratigraphy. Sedimentary Geology, v. 176, p. 67-95.

Catuneanu, O., Abreu, V., Bhattacharya, J.P., Blum, M.D., Dalrymple, R.W., Eriksson, P.G., Fielding, C.R., Fisher, W.L., Galloway, W.E., Gibling, M.R., Giles, K.A., Holbrook, J.M., Jordan, R., Kendall, C.G.St.C., Macurda, B., Martinsen, O.J., Miall, A.D., Neal, J.E., Nummedal, D., Pomar, L., Posamentier, H.W., Pratt, B.R., Sarg, J.F., Shanley, K.W., Steel, R.J., Strasser, A., Tucker, M.E., Winker, C., 2009. Towards the standardization of sequence stratigraphy. EarthScience Reviews, vol. 92, p. 1-33. 
Catuneanu, O., Bhattacharya, J.P., Blum, M.D., Dalrymple, R.W., Eriksson, P.G., Fielding, C.R., Fisher, W.L., Galloway, W.E., Gianolla, P., Gibling, M.R., Giles, K.A., Holbrook, J.M., Jordan, R., Kendall, C.G.St.C., Macurda, B., Martinsen, O.J., Miall, A.D., Nummedal, D., Posamentier, H.W., Pratt, B.R., Shanley, K.W., Steel, R.J., Strasser, A. and Tucker, M.E., 2010. Sequence stratigraphy: common ground after three decades of development. First Break, v. 28, p. 21-34.

Christie-Blick, N., 1991. Onlap, offlap, and the origin of unconformity-bounded depositional sequences. Marine Geology, v. 97, p. 35-56.

Cousens, B.L., Chiarenzelli, J.R., Aspler, L.B., 2004. An unusual Palaeoproterozoic magmatic event, the ultrapotassic Christopher Island Formation, Baker Lake Group, Nunavat, Canada: Archaean mantle metasomatism and Palaeoproterozoic mantle reactivation. In: Eriksson, P.G., Altermann, W., Nelson, D.R., Mueller, W.U., Catuneanu, O. (Eds.) The Precambrian Earth: Tempos and Events. Elsevier, Amsterdam, p. 183-201.

Donaldson, J.A., Eriksson, P.G. and Altermann, W., 2002. Actualistic versus non-actualistic conditions in the Precambrian: a reappraisal of an enduring discussion. In: Altermann, W. and Corcoran, P.L. (Eds.) Precambrian Sedimentary Environments: a Modern Approach to Ancient Depositional Systems. I.A.S. Spec. Publ. 33, Blackwell, Oxford, p. 3-13.

Drummond, C.N. and Wilkinson, B.H., 1996. Stratal thickness frequencies and the prevalence of orderedness in stratigraphic sequences. Journal of Geology, v. 104, p. 1-18.

Embry, A.F., 1995. Sequence boundaries and sequence hierarchies: problems and proposals. In: R.J. Steel, V.L. Felt, V.L., E.P. Johannessen, C. Mathieu (Eds.) Sequence stratigraphy on the Northwest European Margin. Norwegian Petroleum Society (NPF), Special Publication 5, p. 111.

Embry, A.F. and Johannessen, E.P., 1992. T-R sequence stratigraphy, facies analysis and reservoir distribution in the uppermost Triassic-Lower Jurassic succession, western Sverdrup Basin, Arctic Canada. In: T.O. Vorren, E. Bergsager, O.A. Dahl-Stamnes, E. Holter, B. Johansen, E. Lie and T.B. Lund (eds.) Arctic Geology and Petroleum Potential. Norwegian Petroleum Society, Special Publication 2, p. 121-146.

Eriksson, P.G. and Catuneanu, O., 2004. A commentary on Precambrian plate tectonics. In: Eriksson, P.G., Altermann, W., Nelson, D.R., Mueller, W.U., Catuneanu, O. (Eds.) The Precambrian Earth: Tempos and Events. Elsevier, Amsterdam, p. 201-213.

Eriksson, P.G., Condie, K.C., Tirsgaard, H., Mueller, W.U., Altermann, W., Miall, A.D., Aspler, L.B., Catuneanu, O. and Chiarenzelli, J.R., 1998. Precambrian clastic sedimentation systems. Sedimentary Geology, v. 120, p. 5-53.

Eriksson, P.G., Altermann, W., Nelson, D.R., Mueller, W.U., Catuneanu, O. (Eds.), 2004a. The Precambrian Earth: Tempos and Events. Elsevier, Amsterdam, 941 pp. 
Eriksson, P.G., Bumby, A.J., Popa, M., 2004b. Introduction, Chapter 7. In: Eriksson, P.G., Altermann, W., Nelson, D.R., Mueller, W.U., Catuneanu, O. (Eds.) The Precambrian Earth: Tempos and Events. Elsevier, Amsterdam, p. 593-602.

Eriksson, P.G., Bose, P.K., Sarkar, S., Banerjee, S., 2004c. Sedimentation rates. In: Eriksson, P.G., Altermann, W., Nelson, D.R., Mueller, W.U., Catuneanu, O. (Eds.) The Precambrian Earth: Tempos and Events. Elsevier, Amsterdam, p. 675-677.

Eriksson, P.G., Catuneanu, O., Nelson, D.R. and Popa, M., 2005a. Controls on Precambrian sea level change and sedimentary cyclicity. Sedimentary Geology, v. 176, p. 43-65.

Eriksson, P.G., Catuneanu, O., Els, B.G., Bumby, A.J., van Rooy, J.L. and Popa, M., $2005 b$. Kaapvaal craton: changing first-and second-order controls on sea level from c. 3.0 Ga to 2.0 Ga. Sedimentary Geology, v. 176, p. 121-148.

Eriksson, P.G., Simpson, E.L., Eriksson, K.A., Bumby, A.J., Steyn, G.L. and Sarkar, S., 2000. Muddy roll-up structures in siliciclastic interdune beds of the c. 1.8 Ga Waterberg Group, South Africa. Palaios 15, p. 177-183.

Eriksson, P.G., Catuneanu, O., Aspler, L.B., Chiarenzelli, J.R. and Martins-Neto, M.A., $2001 \mathrm{a}$. Preface, special issue: The influence of magmatism, tectonics, sea level change and palaeoclimate on Precambrian basin evolution: change over time. Sedimentary Geology, v. 141/142, p. vii-xi.

Eriksson, P.G., Martins-Neto, M.A., Nelson, D.R., Aspler, L.B., Chiarenzelli, J.R., Catuneanu, O., Sarkar, S., Altermann, W. and Rautenbach, C.J. deW., 2001b. An introduction to Precambrian basins: their characteristics and genesis. Sedimentary Geology, v. 141/142, p. 1-35.

Frazier, D.E., 1974. Depositional episodes: their relationship to the Quaternary stratigraphic framework in the northwestern portion of the Gulf Basin. University of Texas at Austin, Bureau of Economic Geology, Geological Circular, v. 4, no. 1, 28 pp.

Galloway, W.E., 1989. Genetic stratigraphic sequences in basin analysis, I. Architecture and genesis of flooding-surface bounded depositional units. American Association of Petroleum Geologists Bulletin, v. 73, p. 125-142.

Grotzinger, J.P.,1990. Geochemical model for Proterozoic stromatolite decline. American Journal of Sciences, v. 290-A, p. 80-103.

Haq, B.U., 2009. Paleozoic sequence stratigraphy and cycles of sea-level change. International Association of Sedimentologists, 27th meeting, Alghero, Italy, Abstracts Volume, p. 198.

Haq, B.U., Hardenbol, J. and Vail, P.R., 1987. Chronology of fluctuating sea levels since the Triassic (250 million years ago to present). Science, v. 235, p. 1156-1166. 
Helland-Hansen, W. and Gjelberg, J.G., 1994. Conceptual basis and variability in sequence stratigraphy: a different perspective. Sedimentary Geology, v. 92, p. 31-52.

Hunt, D. and Tucker, M.E., 1992. Stranded parasequences and the forced regressive wedge systems tract: deposition during base-level fall. Sedimentary Geology, v. 81, p. 1-9.

Hunt, D. and Tucker, M.E., 1995. Stranded parasequences and the forced regressive wedge systems tract: deposition during base-level fall - reply. Sedimentary Geology, v. 95, p. 147-160.

Jervey, M.T., 1988. Quantitative geological modeling of siliciclastic rock sequences and their seismic expression. In: C.K. Wilgus, B.S. Hastings, C.G.St.C. Kendall, H.W. Posamentier, C.A. Ross and J.C. Van Wagoner (eds.) Sea Level Changes - An Integrated Approach. SEPM Special Publication 42, p. 47-69.

Johnson, J.G. and Murphy, M.A., 1984. Time-rock model for Siluro-Devonian continental shelf, western United States. Geological Society of America Bulletin, v. 95, p. 1349-1359.

Krapez, B., 1996. Sequence-stratigraphic concepts applied to the identification of basin-filling rhythms in Precambrian successions. Austral. J. Earth Sci., v. 43, p. 355-380.

Krapez, B., 1997. Sequence-stratigraphic concepts applied to the identification of depositional basins and global tectonic cycles. Austral. J. Earth Sci., v. 44, p. 1-36.

Miall, A. D., 1991. Stratigraphic sequences and their chronostratigraphic correlation. Journal of Sedimentary Petrology, v. 61, p. 497-505.

Miall, A.D., 1992. Exxon global cycle chart: an event for every occasion? Geology, v. 20, p. 787-790.

Miall, A.D., 1995. Whither stratigraphy? Sedimentary Geology, v. 100, p. 5-20.

Miall, A.D., 1997. The Geology of Stratigraphic Sequences. Springer-Verlag, 433 pp.

Miller, K.G., Mountain, G.S., Browning, J.V., Kominz, M.A., Sugarman, P.J., Christie-Blick, N., Katz, M.E. and Wright, J.D., 1998. Cenozoic global sea-level, sequences, and the New Jersey transect: results from coastal plain and slope drilling. Reviews of Geophysics, v. 36, p. 569-601.

Miller, K.G., Sugarman, P.J., Browning, J.V., Kominz, M.A., Olsson, R.K., Feigenson, M.D. and Hernandez, J.C., 2004. Upper Cretaceous sequences and sea-level history, New Jersey Coastal Plain. Geological Society of America Bulletin, v. 116, no. 3/4, p. 368-393.

Mitchum, R.M., Jr. and Van Wagoner, J.C., 1991. High-frequency sequences and their stacking patterns: sequence stratigraphic evidence of high-frequency eustatic cycles. Sedimentary Geology, v. 70, p. 131-160. 
Mitchum, R.M., Jr., Vail, P.R. and Thompson, S., III, 1977. Seismic stratigraphy and global changes of sea-level, part 2: the depositional sequence as a basic unit for stratigraphic analysis. In: Peyton, C.E. (Ed.) Seismic Stratigraphy - Applications to Hydrocarbon Exploration. American Association of Petroleum Geologists Memoir 26, p. 53-62.

Ohmoto, H., 2004. The Archaean atmosphere, hydrosphere and biosphere. In: Eriksson, P.G., Altermann, W., Nelson, D.R., Mueller, W.U., Catuneanu, O. (Eds.) The Precambrian Earth: Tempos and Events. Elsevier, Amsterdam, p. 361-388.

Pfluger, F. and Sarkar, S., 1996. Precambrian bedding planes - bound to remain. Geological Society of America, Abstract Programs, v. 28, p. 491.

Posamentier, H.W. and Allen, G.P., 1999. Siliciclastic sequence stratigraphy: concepts and applications. Society of Economic Paleontologists and Mineralogists (SEPM), Concepts in Sedimentology and Paleontology \#7, $210 \mathrm{pp}$.

Posamentier, H.W., Jervey, M.T. and Vail, P.R., 1988. Eustatic controls on clastic deposition I conceptual framework. In: C.K. Wilgus, B.S. Hastings, C.G.St.C. Kendall, H.W. Posamentier, C.A. Ross and J.C. Van Wagoner (eds.) Sea Level Changes - An Integrated Approach. Society of Economic Paleontologists and Mineralogists (SEPM) Special Publication 42, p. 110-124.

Sarkar, S., Banerjee, S., Eriksson, P.G. and Catuneanu, O., 2005. Microbial mat control on siliciclastic Precambrian sequence stratigraphic architecture: examples from India. Sedimentary Geology, v. 176, p. 195-209.

Schlager, W., 2004. Fractal nature of stratigraphic sequences. Geology, v. 32, p. 185-188.

Schopf, J.W., 2004. Earth's earliest biosphere: status of the hunt. In: Eriksson, P.G., Altermann, W., Nelson, D.R., Mueller, W.U. and Catuneanu, O. (eds.) The Precambrian Earth: tempos and events. Elsevier, Amsterdam, p. 516-539.

Sloss, L.L., 1963. Sequences in the cratonic interior of North America. Geological Society of America Bulletin, v. 74, p. 93-113.

Sloss, L.L., Krumbein, W.C. and Dapples, E.C., 1949. Integrated facies analysis. In: C.R. Longwell (ed.) Sedimentary Facies in Geologic History. Geological Society of America Memoir 39, p. 91-124.

Vail, P.R., Mitchum, R.M. Jr. and Thompson, S., III, 1977. Seismic stratigraphy and global changes of sea level, part four: global cycles of relative changes of sea level. American Association of Petroleum Geologists Memoir 26, p. 83-98.

Vail, P.R., Audemard, F., Bowman, S.A., Eisner, P.N. and Perez-Cruz, C., 1991. The stratigraphic signatures of tectonics, eustasy and sedimentology - an overview. In: G. Einsele, W. Ricken and A. Seilacher (eds.) Cycles and Events in Stratigraphy. Berlin, Springer-Verlag, p. 617-659. 
Van Wagoner, J.C., Posamentier, H.W., Mitchum, R.M., Vail, P.R., Sarg, J.F., Loutit, T.S., and Hardenbol, J., 1988. An overview of sequence stratigraphy and key definitions. In: C.K. Wilgus, B.S. Hastings, C.G.St.C. Kendall, H.W. Posamentier, C.A. Ross and J.C. Van Wagoner (eds.) Sea Level Changes - An Integrated Approach. Society of Economic Paleontologists and Mineralogists (SEPM), Special Publication 42, p. 39-45.

Van Wagoner, J.C., Mitchum, R.M., Jr., Campion, K.M. and Rahmanian, V.D., 1990.

Siliciclastic sequence stratigraphy in well logs, core, and outcrops: concepts for high-resolution correlation of time and facies. American Association of Petroleum Geologists Methods in Exploration Series 7, 55 pp.

Williams, G.E., 2004. Earth's Precambrian rotation and the evolving lunar orbit: implications of tidal rhythmite data for palaeogeophysics. In: Eriksson, P.G., Altermann, W., Nelson, D.R., Mueller, W.U. and Catuneanu, O. (Eds.), The Precambrian Earth: tempos and events. Elsevier, Amsterdam, pp. 473-482.

\section{Figure captions}

Figure 1. Correlative conformities as defined by different sequence stratigraphic models (from Catuneanu, 2006). The timing of formation of correlative conformities may be independent of sedimentation (models A, B, D and F), or dependent upon sedimentation (models C and E). Abbreviations: LST - lowstand systems tract; HST - highstand systems tract; TST transgressive systems tract; FSST - falling-stage systems tract; RST - regressive systems tract.

Figure 2. Stratal stacking patterns related to shoreline trajectories (from Catuneanu et al., 2010): forced regression, normal regression, transgression. Zigzag lines indicate lateral changes of facies within individual sedimentary bodies. The diagram shows the possible types of shoreline trajectory during changes (rise or fall) in relative sea level. During a stillstand of relative sea level (not shown), the shoreline may undergo sediment-driven progradation (normal regression, where the topset is replaced by toplap), erosional transgression, or no movement at all. However, due to the complexity of independent variables that interplay to control relative sea-level change, it is unlikely to maintain stillstand conditions for any extended period of time. Abbreviation: RSL - relative sea level.

Figure 3. Types of sequence stratigraphic unit: sequences, systems tracts, parasequences. Stratal stacking patterns are central to the definition of any kind of sequence stratigraphic unit, at any scale of observation. All sequence stratigraphic units whose origin relates to changes in shoreline trajectory consist of a combination of forced regressive, normal regressive and transgressive deposits. Abbreviations: FR - forced regressive; NR - normal regressive; T - transgressive.

Figure 4. Evolution of sequence stratigraphic approaches (from Catuneanu et al., 2010).

Figure 5. Nomenclature of systems tracts, and timing of sequence boundaries for the various sequence stratigraphic approaches (modified from Catuneanu et al., 2010). Abbreviations: RSL - 
relative sea level; $\mathrm{T}$ - transgression; $\mathrm{R}$ - regression; FR - forced regression; LNR - lowstand normal regression; HNR - highstand normal regression; LST - lowstand systems tract; TST transgressive systems tract; HST - highstand systems tract; FSST - falling-stage systems tract; $\mathrm{RST}$ - regressive systems tract; T-R - transgressive-regressive; $\mathrm{CC}^{*}$ - correlative conformity in the sense of Posamentier and Allen (1999); CC** - correlative conformity in the sense of Hunt and Tucker (1992); MFS - maximum flooding surface; MRS - maximum regressive surface. References for the proponents of the various sequence models are provided in Figure 4.

Figure 6. Model-independent methodology versus model-dependent choices in sequence stratigraphy (modified from Catuneanu et al., 2009, 2010). The model-independent methodology starts with basic observations and leads to the construction of a sequence stratigraphic framework defined by specific stratal stacking patterns and bounding surfaces. The modeldependent choices refer to the selection of surfaces that should be elevated to the status of sequence boundary. This selection is commonly guided by how well the various surfaces are expressed with the available data in a given succession. 


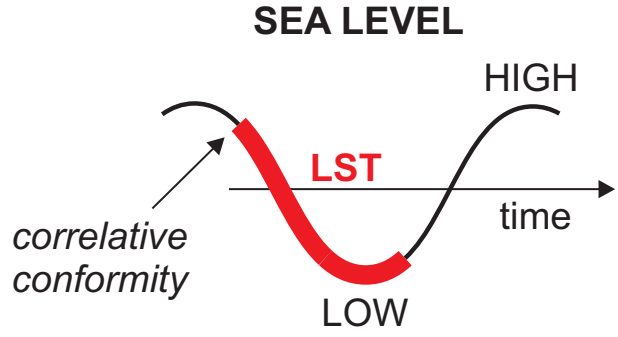

A. Posamentier et al. (1988)

\section{RELATIVE SEA LEVEL}

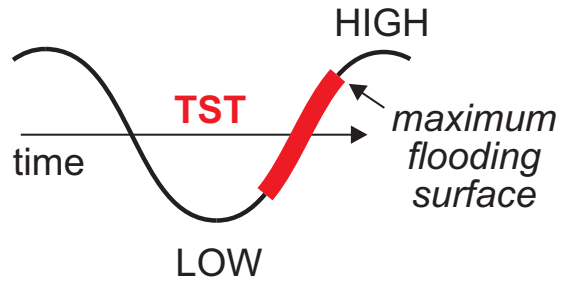

C. Galloway (1989)

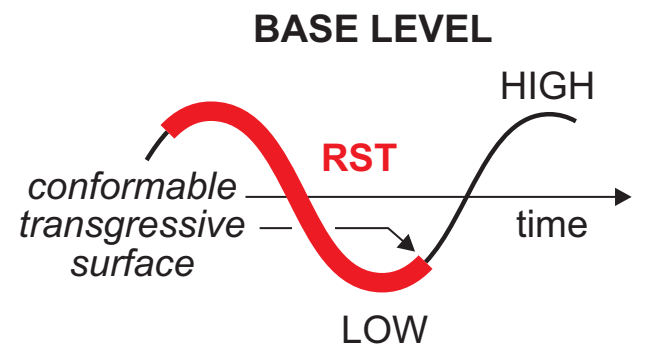

E. Embry and Johannessen (1992)

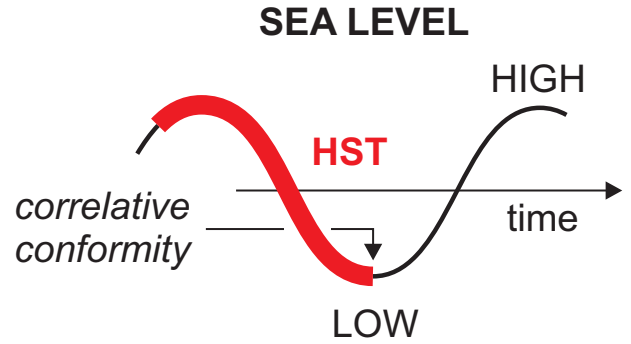

B. Van Wagoner et al. (1988)

\section{RELATIVE SEA LEVEL}

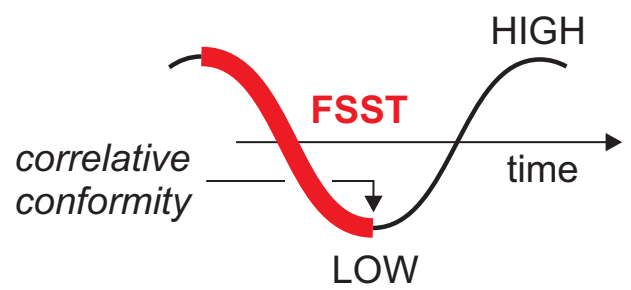

D. Hunt and Tucker (1992)

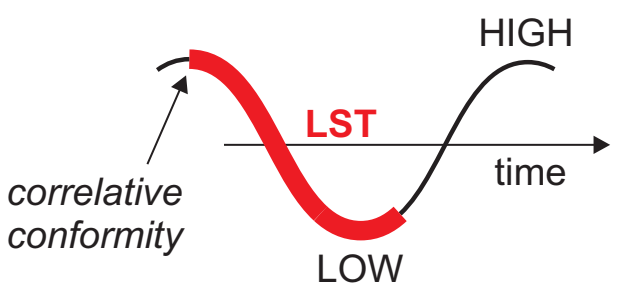

F. Posamentier and Allen (1999) 
Forced regression

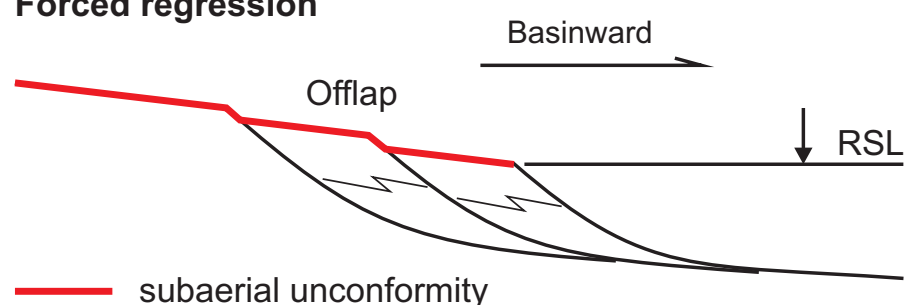

subaerial unconformity
Stacking pattern: progradation with downstepping

Interpretation: progradation driven by relative sealevel fall (negative accommodation). The coastline is forced to regress, irrespective of sediment supply.

\section{Normal regression}

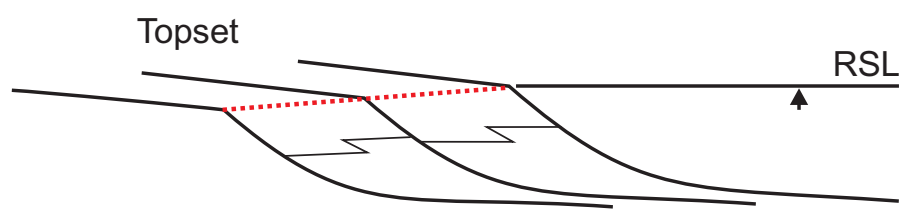

shoreline trajectory

\section{Transgression}

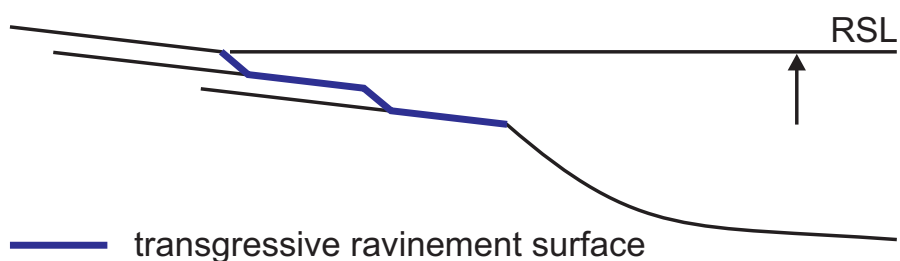

Stacking pattern: retrogradation.

Interpretation: retrogradation (backstepping) driven by relative sea-level rise. Accommodation outpaces the sedimentation rates at the coastline.

Interpretation: progradation driven by sediment supply. Sedimentation rates outpace the rates of relative sealevel rise (positive accommodation) at the coastline. 
Figure 3

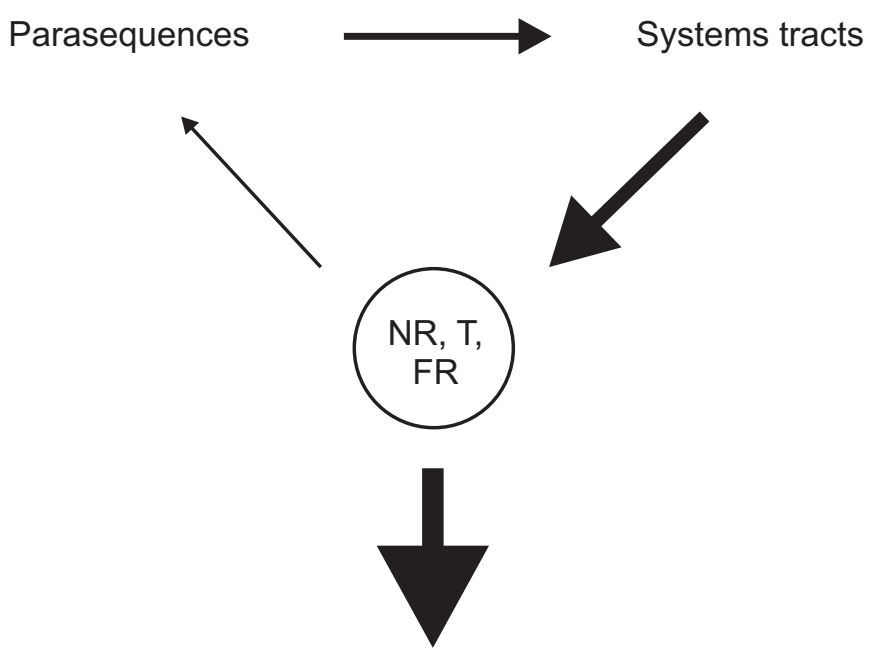

Sequences 


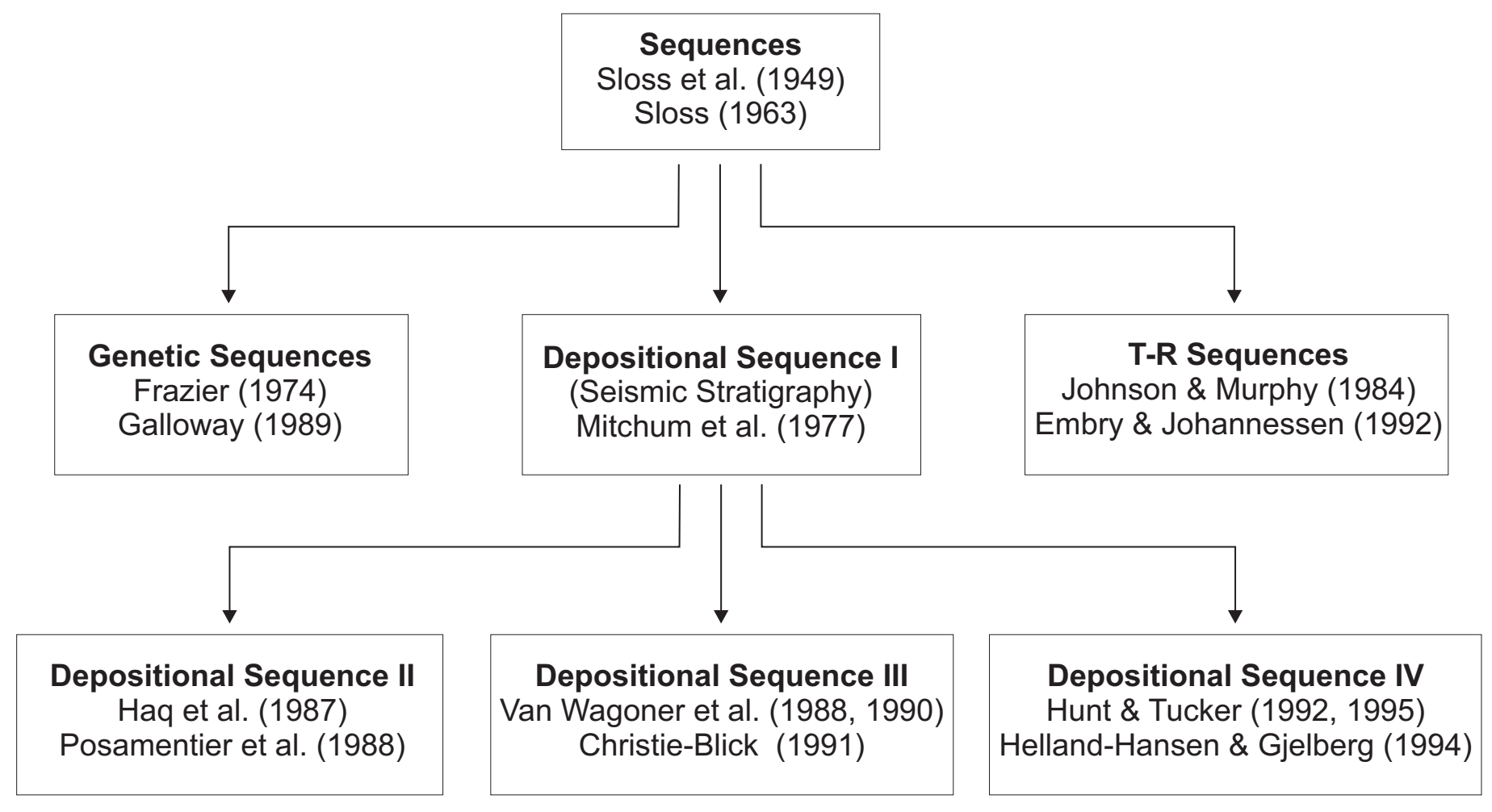




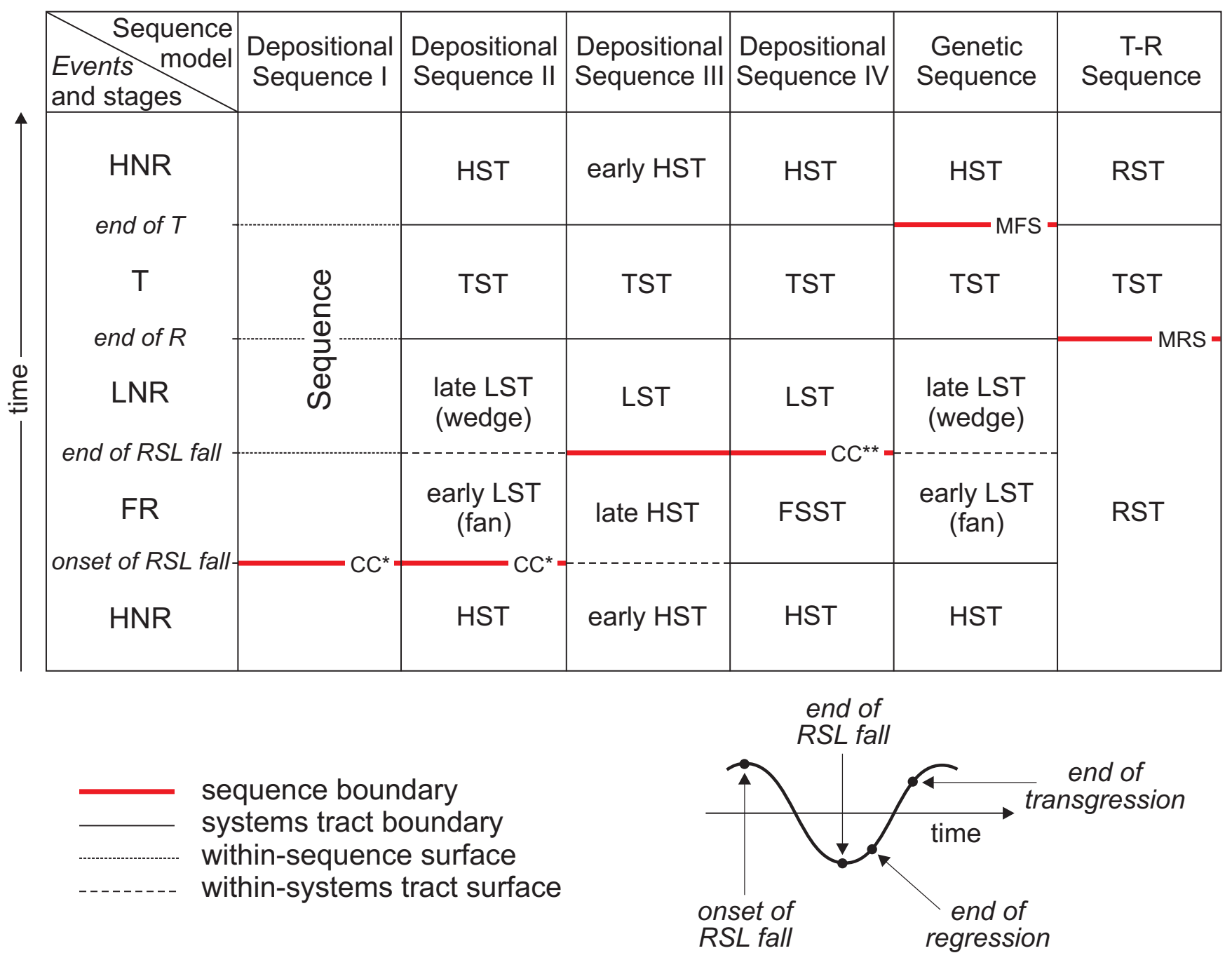


Figure 6

1. Model-independent methodology

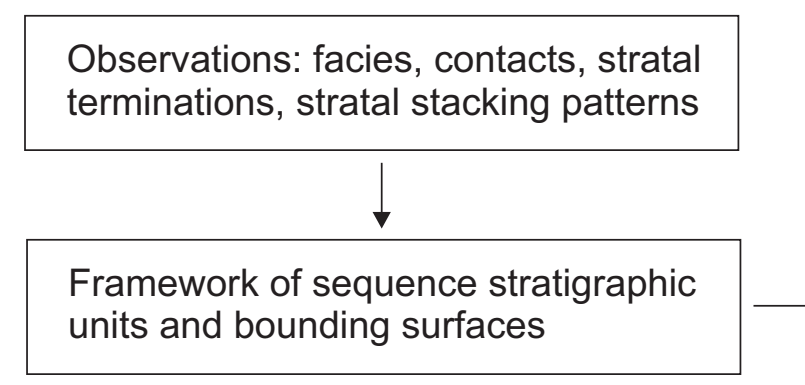

2. Model-dependent choices

Choice of surface(s) that should be selected as 'sequence boundaries'

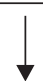

Delineation of specific types of 'sequences' 